\title{
MAPEAMENTO DO PROCESSO HISTÓRICO DE EXPANSÃO URBANA DO MUNICÍPIO DE GOIÂNIA-GO
}

\author{
Diego TARLEy FerReira NASCIMENTO ${ }^{1}$ \\ IVANILTON José DE OLIVEIRA ${ }^{2}$ \\ Universidade Federal de Goiás
}

Resumo: Goiânia é uma cidade relativamente jovem, mas em intenso processo de crescimento urbano. Embora tenha sido planejada, a capital do Estado de Goiás registra nos dias atuais os resultados de décadas de falta de gestão no ordenamento territorial. Objetivando-se evidenciar esses aspectos, foram analisados os documentos legais que deveriam nortear o crescimento urbano de Goiânia e os trabalhos acadêmicos que analisaram tal fenômeno desde a sua gênese - na década de 1930. E para o período compreendido entre as décadas de 1980 e 2010, optou-se pelo mapeamento com base na interpretação de imagens orbitais Landsat 5. Foi definida uma legenda simplificada, com apenas quatro classes (área urbana, agropecuária, cobertura vegetal e corpos hídricos) para permitir uma avaliação comparativa entre os vários períodos, de forma a evidenciar as mudanças ocorridas. Constatou-se que os planos diretores tiveram um papel significativo na definição dos vetores da expansão urbana de Goiânia. Contudo, esses instrumentos foram negligenciados em diversos períodos, resultando em fases de crescimento descontrolado, evidenciado pela presença de vazios urbanos e pela verticalização desarticulada de uma proposta de ordenamento territorial.

Palavras-chave: Mapeamento; Processo Histórico; Expansão Urbana; Goiânia.

\footnotetext{
${ }^{1}$ Geógrafo e professor convidado da Pontifícia Universidade Católica de Goiás. Mestre em Geografia e doutorando do Programa de Pós-Graduação em Geografia da Universidade Federal de Goiás. Contato: diego.tarley@gmail.com.

${ }^{2}$ Geógrafo, professor adjunto da Universidade Federal de Goiás. Doutor em Geografia. Contato: ivanilton.oliveira@gmail.com.
} 


\section{MAPPING THE HISTORICAL PROCESS OF URBAN GROWTH IN GOIÂNIA-GO}

Abstract: Goiânia, capital of Goiás State, is a relatively young city, but it has experienced an intense process of urban growth. Although it was planned, nowadays its space reflects decades of failure in land management. With the aim of highlighting the city's expansion and land use management, we analyzed legal documents governing land use in Goiânia, as well as the academic studies that investigated this phenomenon since the city's foundation in the 1930s. For the period between the 1980s and 2010, we elaborated cartographic material based on satellite images Landsat 5. A simplified legend was defined with only four classes of land use (urban, agricultural, vegetation and water bodies) to enable a comparative evaluation between the various periods and thus to highlight the changes that have occurred. It was found that master plans had a significant role in defining the directions of urban expansion of Goiânia. However, these instruments have been neglected in many periods, resulting in uncontrolled growth phases, as evidenced by the presence of urban voids and unplanned vertical densification.

Keywords: Mapping; Historic Process; Urban Growth; Goiânia.

\section{Introdução}

Fundada em 24 de outubro de 1933, Goiânia pode ser considerada uma cidade relativamente jovem mesmo para os padrões brasileiros, cujas cidades mais antigas remetem ao século XVI. Planejada para ser a nova capital do Estado de Goiás, em substituição à Cidade de Goiás (antiga Vila Boa), Goiânia foi implantada na porção sul do estado (que à época incluía o território do atual Estado do Tocantins), como fruto de um projeto desenvolvimentista que visava aproximar o lócus do poder político goiano em relação à área de maior desenvolvimento econômico nacional, representada pela Região Sudeste.

$\mathrm{O}$ município de Goiânia apresenta seus limites circunscritos às latitudes $16^{\circ} 27^{\prime} 12^{\prime \prime} \mathrm{S}$ e $16^{\circ} 49^{\prime} 52^{\prime \prime} \mathrm{S}$ e longitudes $49^{\circ} 4^{\prime} 38^{\prime \prime} \mathrm{O}$ e $49^{\circ} 26^{\prime} 48^{\prime \prime} \mathrm{O}$ (Figura 1), totalizando uma área de $732 \mathrm{~km}^{2}$. As altitudes variam de 661 a $1.037 \mathrm{~m}$ acima do nível do mar, com média de $785 \mathrm{~m}$. Sua população foi estimada, para 2014, em 1.412.364 habitantes (IBGE, 2012). Juntamente com outros 19 municípios, ela compõe a Região Metropolitana de Goiânia, instituída pela Lei $\mathrm{n}^{\circ} 27$ de 30 de dezembro de 1999, e complementada pela Lei n 78 , de 25 de março de 2010. 


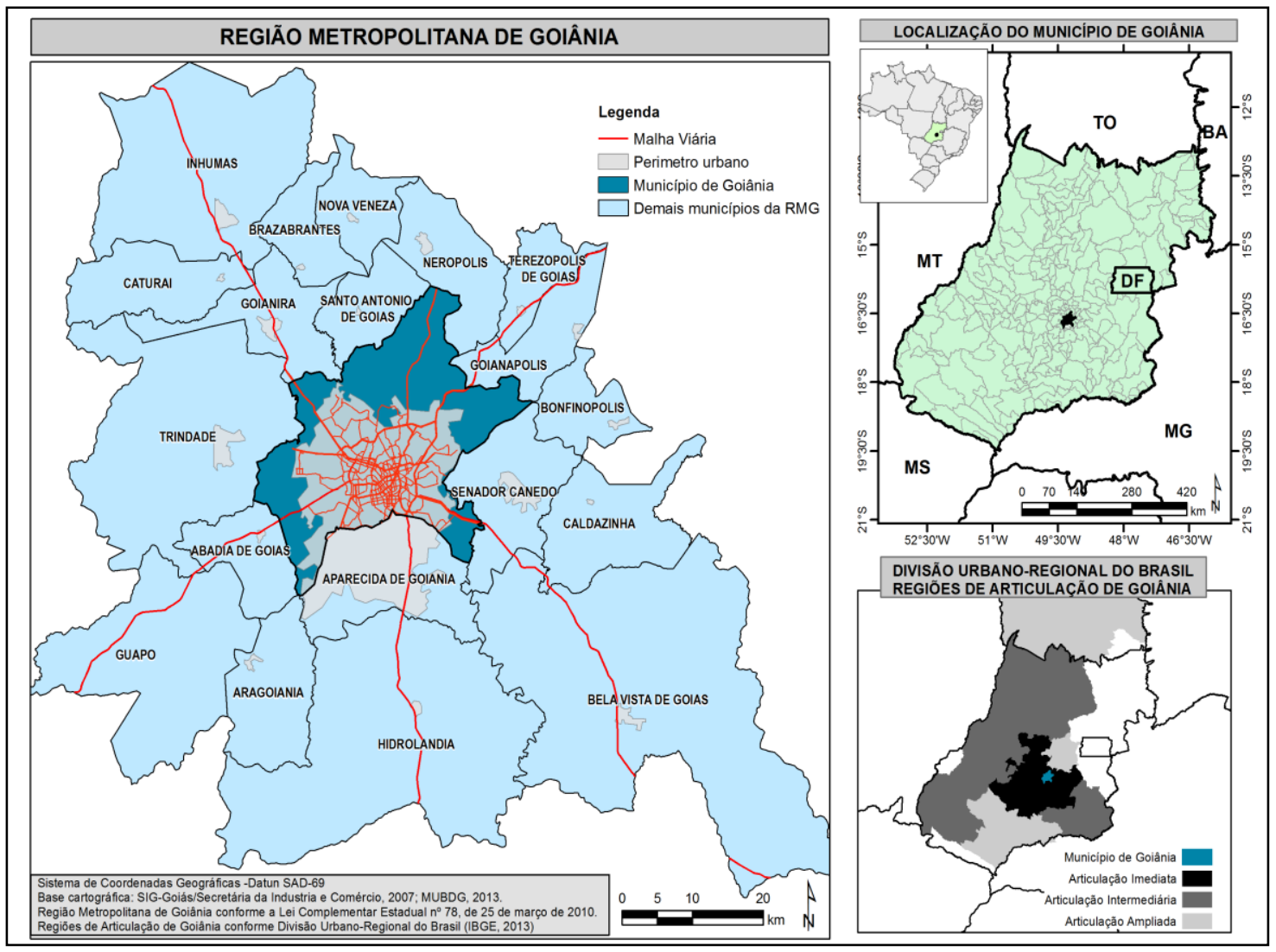

Figura 1: Mapa da Região Metropolitana de Goiânia, localização do município em Goiás e no Brasil e das regiões de articulação urbano-regional de Goiânia.

Fonte: Elaborado pelos autores.

Segundo o estudo das Regiões de Influência das Cidades (REGIC/IBGE, 2008), Goiânia é considerada uma metrópole com porte e projeção nacional, destacandose no comércio, na oferta de ensino superior, na prestação de serviços públicos (principalmente de saúde), na agropecuária e na indústria. Conforme a Divisão Urbano-Regional do Brasil (IBGE, 2013), a capital goiana possui uma região de articulação imediata, que ultrapassa os limites da Região Metropolitana de Goiânia, incorporando outros municípios localizados na porção central do estado - uma região de articulação intermediária, que se estende desde os extremos sudeste e sudoeste ao oeste/noroeste do Estado de Goiás; e uma região de articulação 
ampliada, que se abrange desde o sul do Estado de Goiás até o extremo norte de Tocantins, conforme mostra a Figura 1.

Por possuir características atrativas, Goiânia recebeu forte fluxo de imigrantes, sobretudo advindos dos estados do Maranhão, Pará, Piauí, Bahia e Minas Gerais (RIBEIRO, 2004) o que, acrescido ao processo migratório intraestadual, ao êxodo rural e ao crescimento vegetativo, ocasionou um intenso crescimento demográfico, principalmente entre as décadas de 1950 e 1980, conforme explicitado pelo gráfico representado pela Figura 2, a seguir:

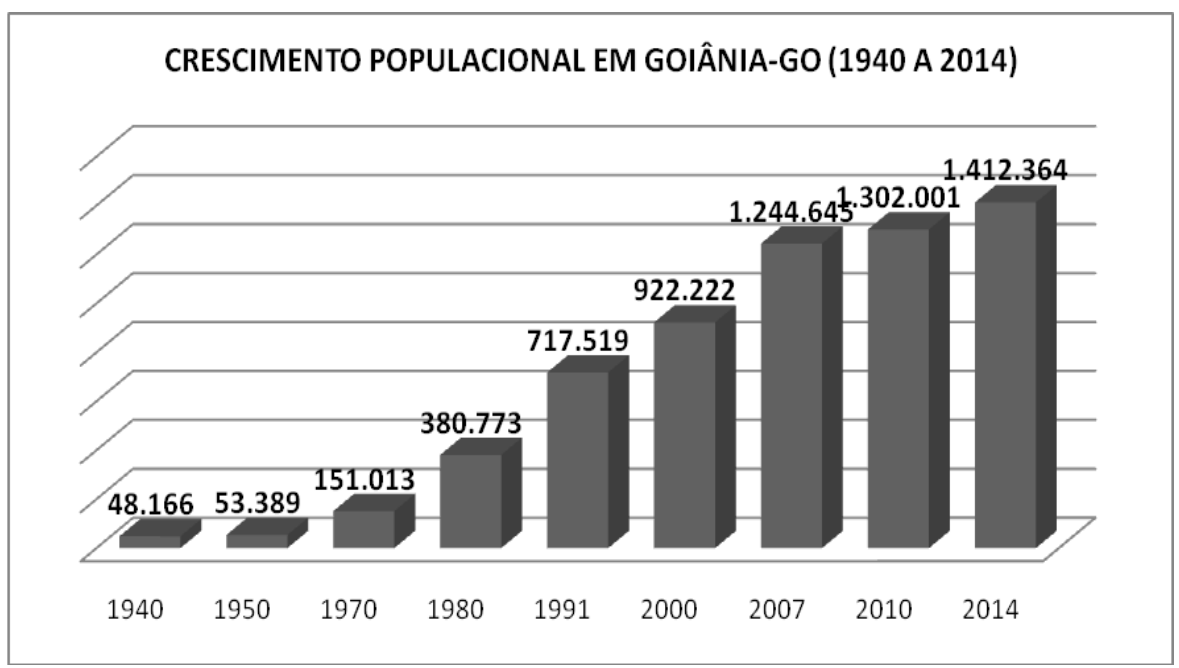

Figura 2: Gráfico do Crescimento Populacional de Goiânia - GO.

Fonte: Elaborado pelos autores com base nos Censos Demográficos do IBGE de 1940, 1950, 1960, 1970, 1980, 1991, 2000, 2007 e 2010 e na Estimativa da População do IBGE, de 2014.

Associado à expansão demográfica houve o crescimento da área urbana do município de Goiânia, fazendo com que este se encontre conurbado em sua porção sul com o município de Aparecida de Goiânia - fenômeno em curso também na região leste, com o município de Senador Canedo; na região noroeste, com Goianira e; na região oeste, com Trindade (ver Figura 1).

Além do processo de conurbação com os municípios vizinhos, o incremento populacional e o respectivo crescimento urbano de Goiânia vêm desencadeando uma gama de impactos ambientais, como é o caso do surgimento e ampliação de diversos processos erosivos, evidenciados por Nascimento (1994) e por Nunes e Romão (2010); da modificação do clima urbano e consolidação do fenômeno de ilha de calor, constatados por Nascimento e Oliveira (2011); da recorrência de 
fenômenos de inundações e alagamentos urbanos, analisados por Rego (2012); da elevação das máximas da temperatura do ar e da redução da umidade relativa do ar, verificadas no trabalho de Luiz (2012); e da perda da cobertura vegetal, reduzida pela metade somente no período entre 1980 e 2010, conforme apurado por Streglio, Nascimento e Oliveira (2012).

Tais problemas resultam, em grande parte, do crescimento acelerado da mancha urbana sem o devido planejamento do uso e ocupação do solo. A despeito da existência de planos diretores para o município de Goiânia desde a sua criação, o que se constata é a inobservância na aplicação e na fiscalização do cumprimento das leis. Tendo esta premissa como ponto de partida, o presente trabalho ancorado, sobretudo, no método cartográfico -, objetiva analisar esse processo histórico de crescimento urbano de Goiânia e evidenciar os vetores e condicionantes dessa expansão urbana.

\section{Procedimentos Metodológicos}

O trabalho se pautou por duas etapas principais e sequenciais. A primeira envolveu a pesquisa documental e bibliográfica. O levantamento documental objetivou reunir informações sobre leis, decretos e normas que regulamentaram o crescimento urbano de Goiânia, a exemplo dos planos diretores e das leis de parcelamento e uso do solo, de edificações e de zoneamento. Também buscou compilar bases cartográficas digitais da malha urbana da capital. O levantamento bibliográfico visou realizar uma ampla revisão teórica sobre o processo de crescimento urbano em Goiânia, por meio de trabalhos publicados em artigos, livros, dissertações e teses, disponíveis em bases de dados digitais com livre acesso - a exemplo do Portal Capes, da Scielo (Scientific Electronic Library Online) e de bancos de dissertações e teses disponíveis -, sendo priorizados aqueles que continham mapeamentos da área urbana da região até a década de 1980.

Por conta do implemento e do desenvolvimento de sistemas de satélite e pela disponibilização de imagens gratuitamente, o crescimento urbano de Goiânia posterior à década de 1980 foi analisado pelo procedimento de classificação digital de imagens de satélite. Para tanto, foram coletadas as imagens registradas pelo sensor TM (Thematic Mapper) a bordo do satélite Landsat 5, no catálogo de imagens do Instituto Nacional de Pesquisas Espaciais (INPE) referentes às bandas 3, 4 e 5 de órbita/ponto 221-71 e 221-72 (que recobrem a área do município de Goiânia), em intervalos de aproximadamente cinco anos, conforme apresentado no Quadro 1. 


\begin{tabular}{|c|}
\hline DATA DAS \\
IMAGENS \\
\hline 23 de maio de 1986 \\
\hline 06 de junho de 1991 \\
\hline 02 de maio de 1996 \\
\hline 30 de junho de 2000 \\
\hline 17 de julho de 2006 \\
\hline 12 de julho de 2010 \\
\hline
\end{tabular}

Quadro 1: Data das imagens orbitais selecionadas.

As imagens orbitais foram pré-processadas com a realização dos procedimentos de georreferenciamento (registro), junção das cenas que compõem a área de estudo (mosaico) e recorte da área do município de Goiânia (máscara), sendo, em seguida, executado o processamento digital por meio de classificação supervisionada com coleta de amostras e aplicação do algoritmo mahalanobis para o agrupamento dos pixels com valores digitais aproximados aqueles das amostras. Ressalta-se que, após a classificação das imagens, foi realizado o processo de inspeção visual com imagens de maior resolução (Google Earth) para a correção e validação da classificação, com edição dos vetores delimitados equivocadamente. Toda essa etapa foi conduzida no software ArcGIS 9.3.

Em função dos objetivos do trabalho, optou-se pela definição de uma legenda simplificada, com apenas quatro classes: área urbana, agropecuária, cobertura vegetal e corpos hídricos. Essas tipologias facilitaram uma avaliação comparativa entre os vários períodos, para evidenciar as mudanças ocorridas.

Convém frisar, ainda, que pelo fato da resolução espacial das imagens do satélite Landsat 5 ser de $30 \mathrm{~m}$, foi possível alcançar a escala de 1:100.000 (BOGGIONE et al., 2009), sendo fixada esta escala no software ArcGIS 9.3 para a visualização e validação do mapeamento de cobertura e uso do solo. 


\section{Resultados e Discussões}

\section{Histórico do crescimento urbano de Goiânia até a década de 1980}

Conforme destacado por Aroldo de Azevedo (1941), Goiânia pode ser considerada uma cidade "criada", uma vez que ela foi planejada desde sua concepção para substituir a até então capital do Estado de Goiás (Vila Boa, atualmente Cidade de Goiás) devido às características fisiogeográficas e sanitárias ali presentes. Sobre as condições de habitação da antiga capital do Estado, Azevedo (1941) apresenta uma descrição redigida pelo presidente do Estado, Dr. Rodolfo Gustavo da Paixão, datada de agosto de 1890:

A capital de Goiaz é, sem dúvida, uma daquelas cidades cujo estado sanitário, dia a dia pior, reclama às mais prontas e enérgicas providências. Situada em meio de uma bacia, conquanto sôbre terreno acidentado, cercada de altos montes que comprimem em diminuto âmbito, embaraçando-lhe a regular ventilação, estreitando-lhe, demais, o horizonte visual; castigada por excessiva temperatura graças à sua baixa latitude de quase $16^{\circ} \mathrm{Sul}$, não corrigida pela altitude ou por causas locais; com uma edificação à antiga, obedecendo, in totum, à arte colonial, que era antes a negação dos mais rudimentares princípios arquitetônicos e dos mais salutares preceitos da moderna higiene, espreguiçando-se às margens do rio Vermelho, mas curtindo verdadeira sêde de Tântalo, visto como a água viscosa dêste ribeiro, despejo e lavadouro da população, não é e nem pode ser convenientemente distribuída às casas, e porque a fornecida pelo único chafariz existente e parcas fontes carece das condições de abundância e necessária potabilidade; desprovida de bom sistema de esgostos, capaz de evitar o uso prejudicialíssimo das latrinas perfuradas no terreno, onde as matérias fecais sem escoamento entram em rápida decomposição e exalam deletérios miasmas e, absorvidas pelo subssolo, bastante permeável, comunicam-se com os poços de serventia, de ordinário abertos nas proximidades daquelas focos de infecção, a decadente Vila-Boa hospeda em seu seio poderosos agentes de destruição, que hão de, em breve, transformá-la em vasta Necrópole, onde a morte campeie com todo o seu cortejo de horrores. 


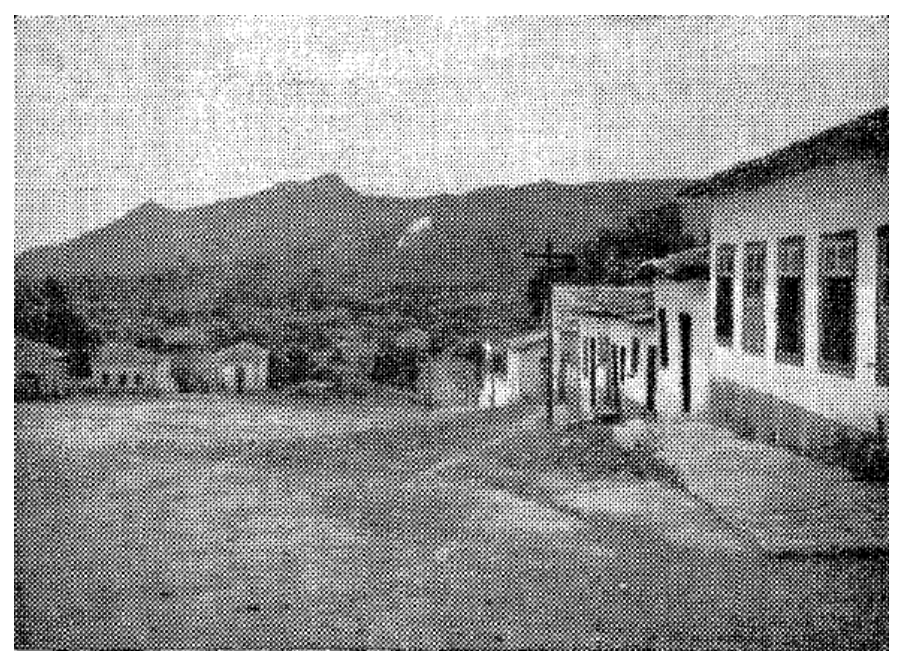

Figura 3: Vista parcial da velha Cidade de Goiás.

Fonte: Azevedo (1941).

Este quadro de problemas posto em evidência, veio se somar ao momento de transição política, ideológica e social do país, que já se refletia em Goiás (CHAUL, 1999; RIBEIRO, 2004) e ajudou a sustentar a decisão sobre a mudança da capital do Estado. Os principais agentes envolvidos com essa mudança foram o interventor federal do Estado de Goiás, Pedro Ludovico Teixeira, e o presidente Getúlio Vargas. Portanto, a necessidade da transferência da capital extrapolava os interesses locais e regionais, como destaca Ribeiro (2004).

No final do ano de 1932 foi definida uma comissão encarregada da escolha do sítio para a nova capital do Estado, sendo apresentadas como propostas as localidades correspondentes às cidades de Bonfim (atualmente denominada de Silvânia), Pires do Rio e Campinas. Após estudos minuciosos acerca das características climática, topográfica, hidrológica e sanitária dessas três propostas, foi escolhido o município de Campinas, às margens dos córregos Botafogo e Capim Puba e compreendendo as fazendas Criméia, Vaca Brava e Botafogo (AZEVEDO, 1941).

Azevedo (1941) lembra que para a escolha do nome da cidade foi realizado um concurso no periódico goiano $O$ Social, tendo sido indicados vários nomes, como: Anhanguera, Crisópolis, Heliópolis, Tupirama, Americana, Petrolândia, Goiânia, Goianópolis, Bartolomeu-Bueno, Guaracima, Campanha, Esplanada, Eldorado, Perutaba, Araguaiana, Liberdade, Marataíra, Paranaguai, Goianésia, Buenópolis, Pátria-Nova, Maraúba e Aspirópolis. Mesmo sendo o nome de Petrolina o mais votado, pelo "decreto de 2 de agosto de 1935, o governo do estado adotou o nome de Goiânia, que havia sido sugerido por apenas dois leitores de 'O Social'" (AZEVEDO, 1941, p. 13). 
Os condicionantes legais e as restrições físicas de crescimento urbano de GoiâniaGO

Foi de autoria de Atílio de Correia Lima a concepção do primeiro Plano Diretor de Goiânia, em 1933 (ver Figura 4-A), reformulado posteriormente pelo Plano de Urbanização desenvolvido por Armando Augusto de Godoy, em 1938 (conforme Figura 4-B).

O plano inicial de Goiânia foi projetado para abrigar uma população de 50 mil habitantes (AZEVEDO, 1941) e inspirado no projeto urbanístico das cidadesjardins, concebido por Ebenezer Howard no final do século passado na Inglaterra. A estrutura original do plano da cidade é do tipo rádio-concêntrico, tendo as principais ruas e avenidas convergindo para a Praça Cívica, dando-lhe destaque e fácil localização e acesso. As outras ruas desenvolvem círculos concêntricos no sul e em diagonal no norte (Figura 5). Os demais setores previstos nesse plano foram organizados em malhas ortogonais, respeitando a topografia do sítio. No projeto inicial, foram definidas cinco zonas: o Centro Cívico, o Centro Comercial, as Áreas Urbanas e Suburbanas, a Zona Industrial (ao norte do sítio) e a Zona Residencial.

A

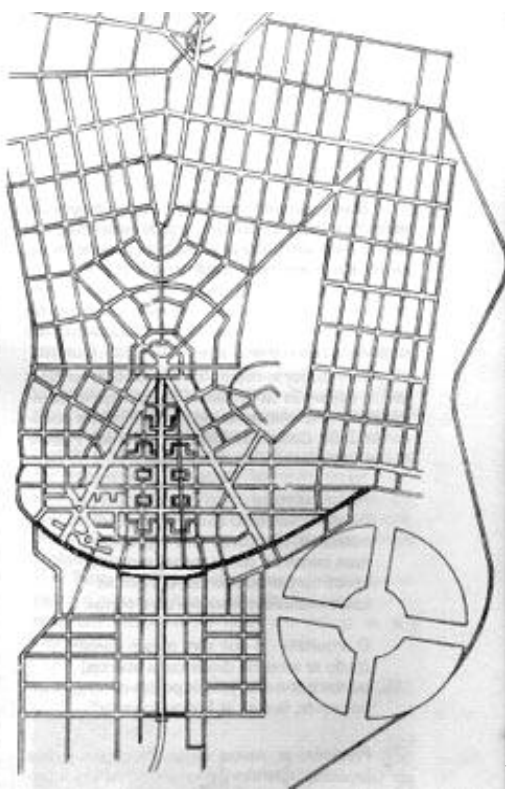

B

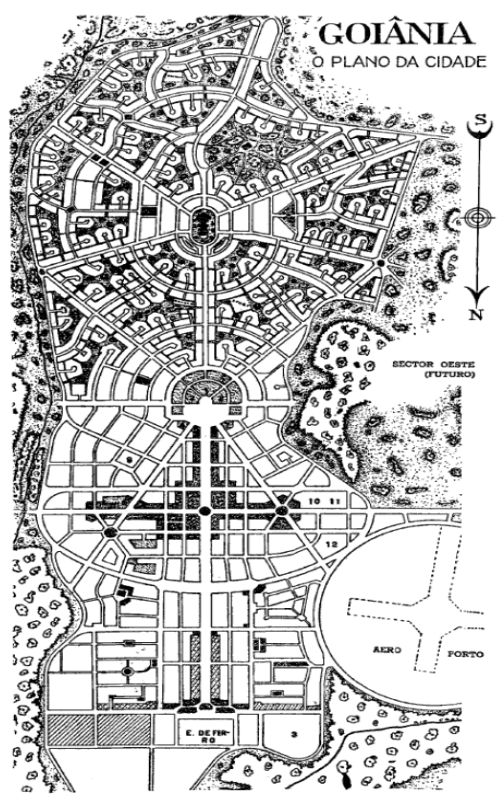

Figuras 4: $O$ plano inicial de Goiânia, elaborado por Atílio Correia de Lima em 1933 (A) e reformulado por Armando Augusto de Godoy, em 1938 (B).

Fonte:

Corrêa

(1981). 
As maiores modificações sugeridas por Godoy, em 1938, ao Plano inicial de Goiânia dizem respeito ao estabelecimento da Praça do Cruzeiro (no seguimento da Praça Cívica), à criação de quatro novas zonas (Zonas de Diversões, Zona Universitária, Zona Militar e a Zona Residencial de Luxo) e à redefinição dos limites dos setores e das áreas livres. Mas a principal contribuição de Godoy ao planejamento do crescimento de Goiânia foi à indicação de etapas de expansão da cidade: primeiramente a ser realizada nos setores central e norte; após seis anos, no setor sul; e, apenas posteriormente, no setor oeste. Porém, encontrando a ferrovia, um relevo mais acentuado e os mananciais de abastecimento da cidade (Córregos Botafogo e Capim Puba) como restrição física ao norte, a cidade apresentou duas expansões delimitadas: uma ao sul, onde se situavam as terras adquiridas pelo Estado para implantação de loteamentos, e outra a oeste (OLIVEIRA, 2005).

Corrêa (1981) destaca como restrições físicas que tiveram influência no crescimento urbano de Goiânia a instalação da Rede Ferroviária, que impediu o crescimento a partir do extremo norte do Setor Central até a década de 1960; a Rodovia BR-153, que representou obstáculo à expansão urbana para o leste/sudeste até meados da década de 1980; e o rio Meia Ponte, que até a década de 1990 restringiu o crescimento urbano pela falta de pontes, o que não impediu a ocupação de seus fundos de vale. Também pode ser incluída entre as restrições ao crescimento a presença da área de captação de água no próprio rio Meia Ponte, na parte noroeste do município de Goiânia, o que exigia a presença de uma zona tampão não disponível para loteamento, para proteger a vida útil do ponto de captação.

Sobre isso, Azevedo (1941) complementa que o plano geral da cidade obedeceu a três condicionantes principais: a topografia, uma vez que as ruas e avenidas foram traçadas seguindo a direção geral das curvas de nível (evitando a formação de enxurradas); o traçado da malha viária, fazendo fluir o tráfego por grandes avenidas com acesso ao centro administrativo; e o zoneamento, pois em seu plano original a cidade foi setorizada nas zonas administrativa, comercial, industrial e residencial.

Houve também no Plano Inicial reformulado por Godoy em 1938 a previsão da instalação de cidades satélites e a intenção da disposição de um cinturão verde composto por parques, parkways, jardins, playgrounds, praças e áreas verdes - com a função de proteger e conservar a cidade.

Em 1947 foi aprovado o Código de Edificações de Goiânia, outro importante instrumento legal de planejamento que abrangia toda a legislação urbana (Lei de Zoneamento, Lei de Loteamentos, Lei de Uso e Ocupação do Solo), que permitia à iniciativa privada a execução de novos loteamentos, desde que fosse obedecida a obrigatoriedade da implantação de toda a infraestrutura por parte dos 
empreendedores. Contudo, o Decreto $\mathrm{n}^{\circ} 16$, de 20/06/1950, passou a exigir do empreendedor apenas a locação e a abertura de vias. Pode-se afirmar que, a partir deste momento, o poder público municipal abriu mão do controle sobre o uso do solo na capital.

A esse respeito, Oliveira $(2005$, p. 4) destaca que "até 1950, a formação do espaço urbano de Goiânia respeitou os planos iniciais e teve seu crescimento 'monitorado' pelo Estado". Fato este que não perdurou nas décadas seguintes, haja vista o avanço acelerado do número de loteamentos feitos pela iniciativa privada nas décadas de 1950 e 1960, principalmente nas regiões Leste e Oeste (ver Figura 5), destinados à população crescente, em grande parte composta por migrantes com poucas condições financeiras.

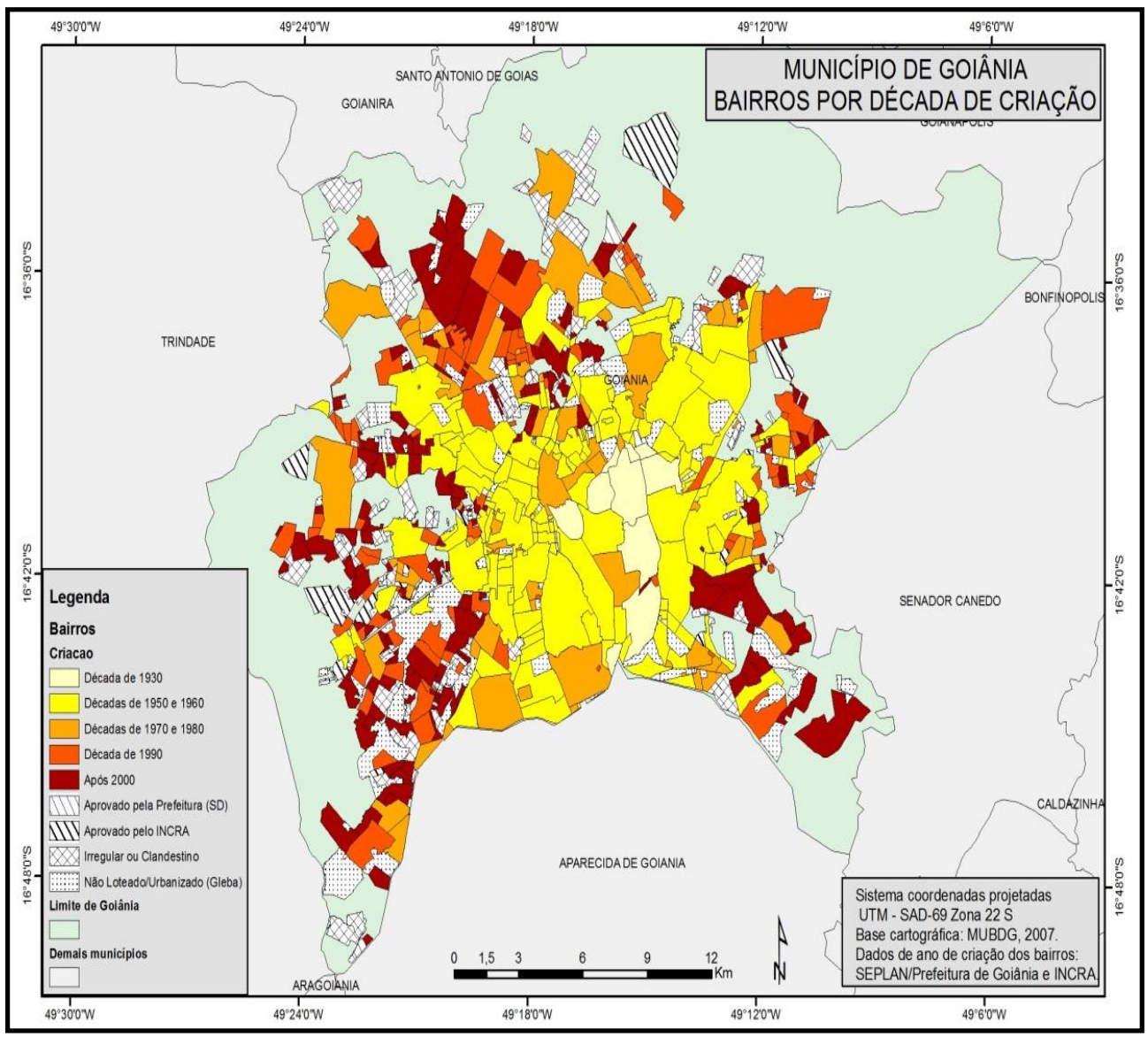

Figura 5: Mapa dos bairros de Goiânia - GO por década de criação.

Fonte: Streglio, Nascimento e Oliveira (2013). 
Em 1959, o arquiteto Luís Saia foi convidado pela Prefeitura para desenvolver um novo Plano Diretor para Goiânia. Neste plano, o arquiteto abordou aspectos da história e da administração e identificou as barreiras urbanas, as áreas de atração/polarização e a estrutura urbana, além de compartimentar a cidade em zonas para a definição de soluções específicas. O trabalho foi concluído em 1962, porém, devido ao movimento político que deflagrou o golpe militar e a implantação do regime autoritário de 1964, esse Plano Diretor não chegou a ser efetivado, por ter sido considerado como um "produto do comunismo" (RIBEIRO, 2004).

Neste período, o Estado perde a exclusividade sobre o uso do solo, permitindo que a iniciativa privada assumisse o parcelamento, e sem o ônus da infraestrutura o que possibilitou a descaracterização do plano de concepção da cidade. Sobre isso, Oliveira (2005) destaca a multiplicação de loteamentos irregulares entre a década de 1960 e meados da década de 1970 - tanto na porção central e sul, quanto, sobretudo, nas regiões periféricas das regiões norte e oeste da cidade, conforme demonstra a Figura 5.

No final da década 1960, por iniciativa do Estado, foi elaborado o Plano de Desenvolvimento Integrado de Goiânia (PDIG), com a participação do arquiteto e urbanista Jorge Wilheim. O PDIG foi aprovado em 1971 e traçou um diagnóstico da situação urbanística de Goiânia, identificando uma séria deficiência de infraestrutura especialmente no tocante à pavimentação de ruas, além de fornecer um prognóstico para o desenvolvimento espontâneo da cidade, que ocorreria da seguinte forma: ocupação dos dois lados da BR-153; ocupação do vale alagadiço do Ribeirão Anicuns; extravasamento para o município vizinho ao sul (Aparecida) e; ocupação ao longo das estradas que ligam a capital a Guapó, Trindade e Inhumas. Tal crescimento provocaria o surgimento de muitos loteamentos aleatórios, dificultando a atuação da Prefeitura, tanto no planejamento quanto no atendimento das demandas por serviços e infraestrutura (PDIG, 1992).

Para evitar tal situação, o PDIG orientou o crescimento de Goiânia para o oeste por meio da consolidação da infraestrutura para aquela região, especialmente com a instalação de malha viária e a pavimentação asfáltica, condicionando a expansão da cidade para as regiões sul, sudoeste e oeste.

Pelo estabelecimento de metas programadas de acordo com os recursos da Prefeitura, o PDGI de 1969 teve um relativo sucesso, uma vez que no período de sua vigência foram implantados dezenas de conjuntos habitacionais na periferia da cidade, conforme apontado por Oliveira (2005), e houve uma ampliação considerável da malha asfáltica, consolidando a expansão urbana para as regiões sul (o que ocasionou a conurbação com Aparecida), sudoeste e oeste. No entanto, cabe destacar que a definição dos locais para instalação dos conjuntos 
habitacionais - todos afastados da área urbana já consolidada - significou a criação de imensos espaços vazios no interior da mancha urbana, em grande parte controlados por especuladores imobiliários interessados na valorização futura destes imóveis.

No período compreendido entre as décadas de 1960 e 1980, Goiânia experimentou um rápido crescimento da população (conforme visto na Figura 2). No mesmo período iniciou-se o processo de verticalização (Figura 6), a princípio concentrado nos setores mais antigos e com maior densidade populacional - como o Centro e o Setor Oeste (a exceção foi o Setor Sul, com restrições à instalação de edifícios, conforme demonstra a Figura 7.

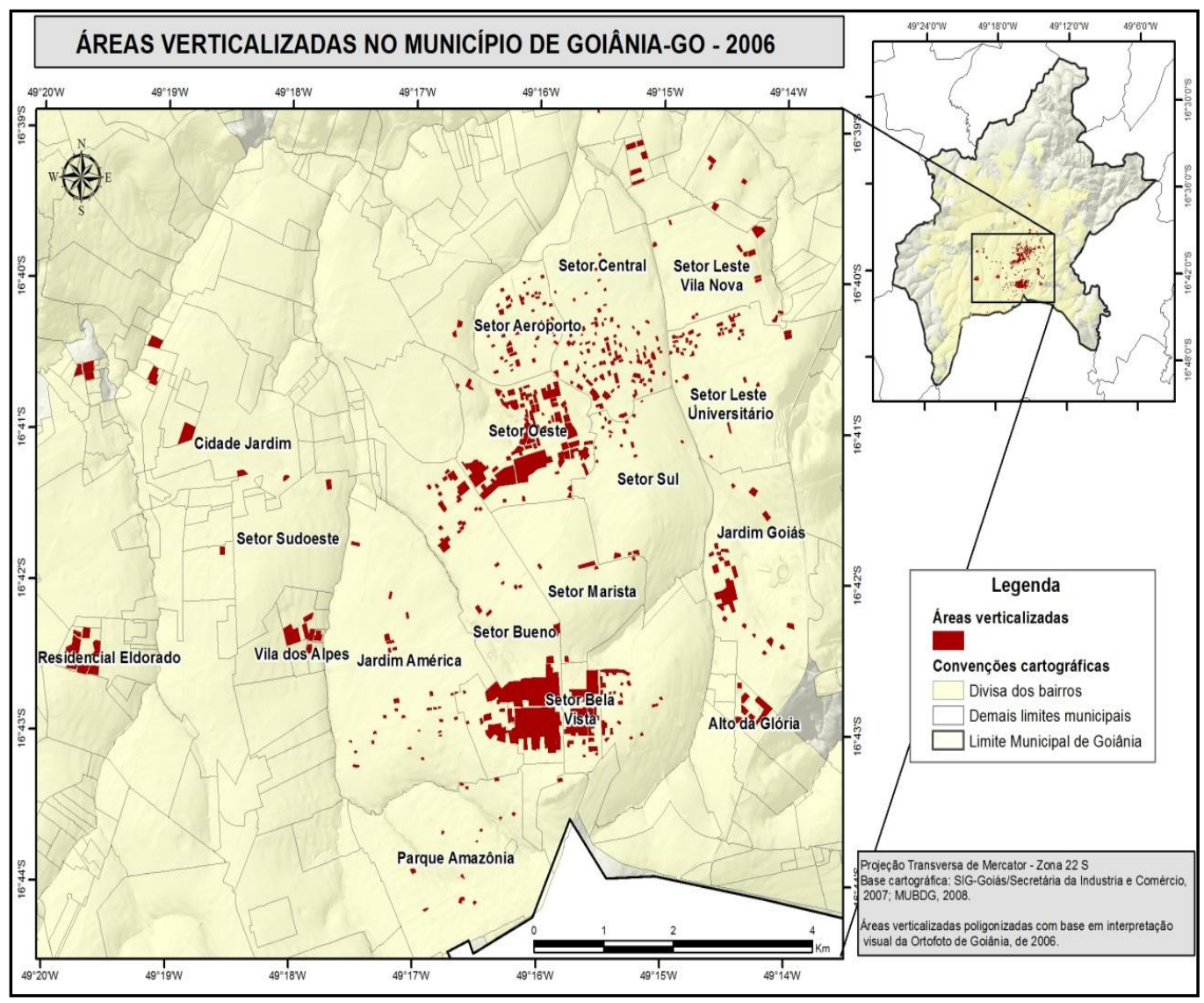

Figura 6: Mapa das áreas verticalizadas em Goiânia - GO, delimitadas com base em imagem QuickBird de 2006.

Fonte: Elaborado pelos autores. 


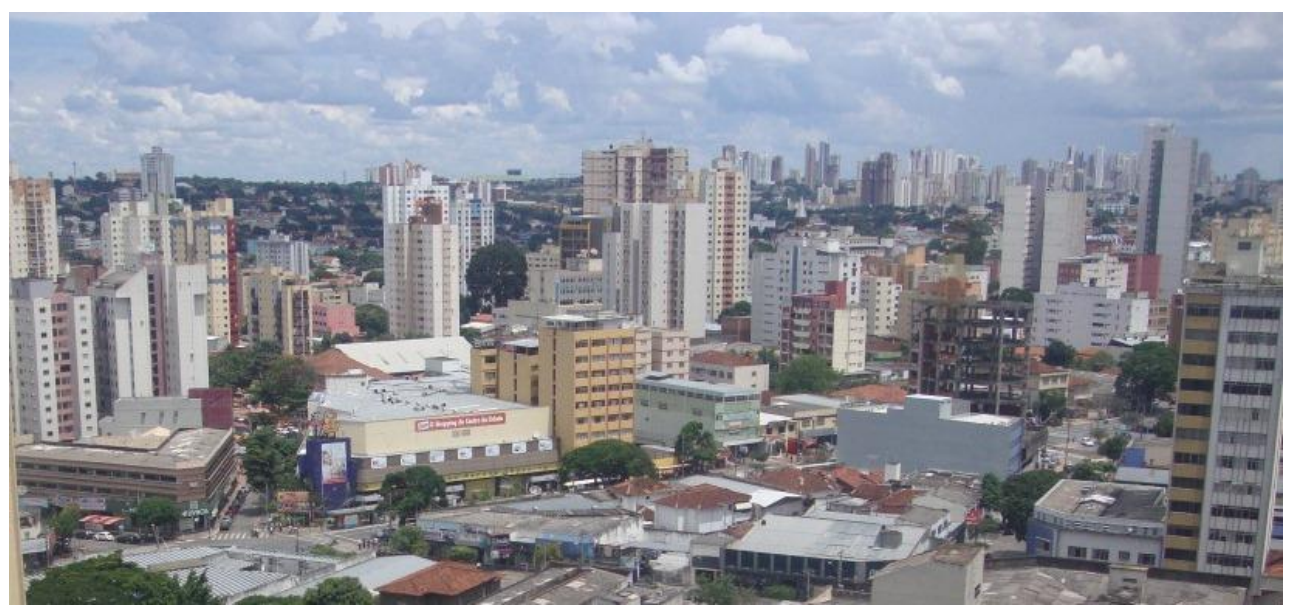

Figura 7: Panorâmica do Setor Central e, em segundo plano à direita, o setor Oeste de Goiânia. Fonte: Nascimento (2011).

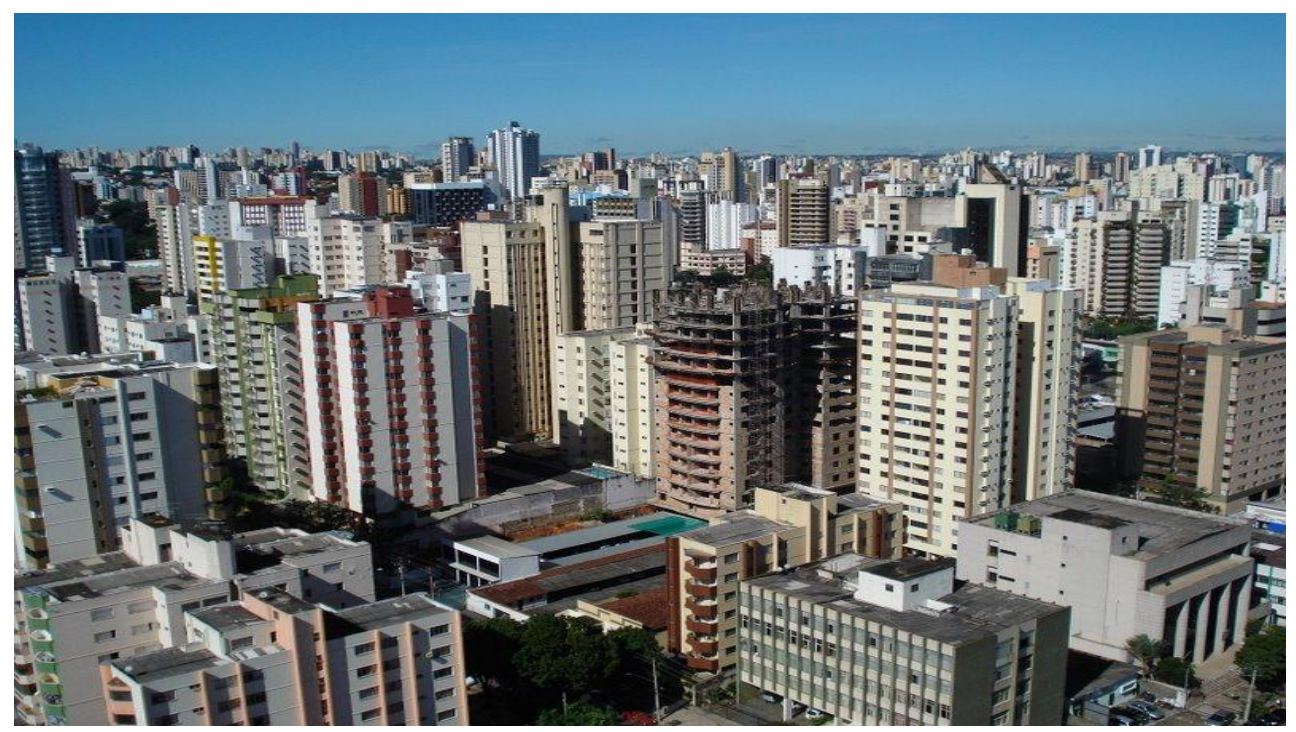

Figura 8: Panorâmica do Setor Bueno e, em segundo plano à direita, o setor Bela Vista de Goiânia.

Fonte: Disponível em: http//:www.skyscrapercity.com. Acessado em: 12 nov. 2013.

Conforme destacado por Pereira, Nascimento e Oliveira (2012), a partir do final da década de 1970 e principalmente ao longo das décadas de 1980 e 1990, a verticalização concentrou-se na parte alta do Setor Bueno, nova e não contígua aos 
bairros mais antigos (ver Figura 8). A partir de então houve um alastramento por diversos bairros, como os do Setor Oeste, Setor Bela Vista, Setor Aeroporto, Setor Leste Universitário - sem qualquer critério urbanístico -, o que apenas reafirma a perda de controle do poder público sobre o processo de crescimento da capital.

$\mathrm{O}$ aparecimento de novas tendências de crescimento, associado às demandas por construção de equipamentos de educação, saúde, infraestrutura, transporte coletivo, dentre outras, fez necessário uma nova proposta do Plano de Desenvolvimento Integrado de Goiânia (PDIG), reformulado em 1992. Conforme relatado no texto deste PDIG, objetivava-se compatibilizar a ordenação do território municipal com o desenvolvimento econômico e social, à proteção do patrimônio cultural e ambiental e ao ordenamento do crescimento da cidade. Além disso, foram observadas as diretrizes da Lei Orgânica do Município, aprovada em 1990, que teve como destaque o fato de estipular a função social da propriedade urbana.

Cumprindo algumas de suas principais metas, o PDIG de 1992 orientou o crescimento urbano de Goiânia para sudoeste; a preservação dos recursos ambientais; a revitalização das áreas centrais; a ocupação prioritária dos vazios urbanos; a estruturação da rede viária básica e; a adequação da distribuição dos equipamentos públicos.

Em 1993 foi elaborada a Carta de Risco de Goiânia, um documento de ordenamento de ocupação urbana que expressava "possíveis situações de perigo, dano ou perda social, econômica e ambiental consequência seja de acontecimento natural ou tecnológico" (NASCIMENTO; PODESTÁ FILHO, 1993, p. 94).

Com base na síntese dos atributos do relevo, dos solos, da geologia, da geomorfologia, da declividade, da vegetação, da susceptibilidade à incidência de processos erosivos, assoreamento, desmoronamentos e deslizamentos e das formas de ocupação feita a partir de uma visão holística, a Carta de Risco determinou como áreas aptas à ocupação urbana a porção centro-sul (no mapa representado pela Figura 9-A, em azul e rosa) e sudoeste (em bege e laranja), com indicação de adoção de medidas de contenção aos processos erosivos e de obras de drenagem urbana. Por sua vez, o documento indicou como áreas impróprias à ocupação urbana as planícies, os terraços e os fundos de vale (em vermelho, marrom e verde claro, respectivamente) e toda a porção norte e nordeste do município (em amarelo e roxo), com a indicação da necessidade de destinação destas áreas à preservação ambiental e recarga de mananciais. 


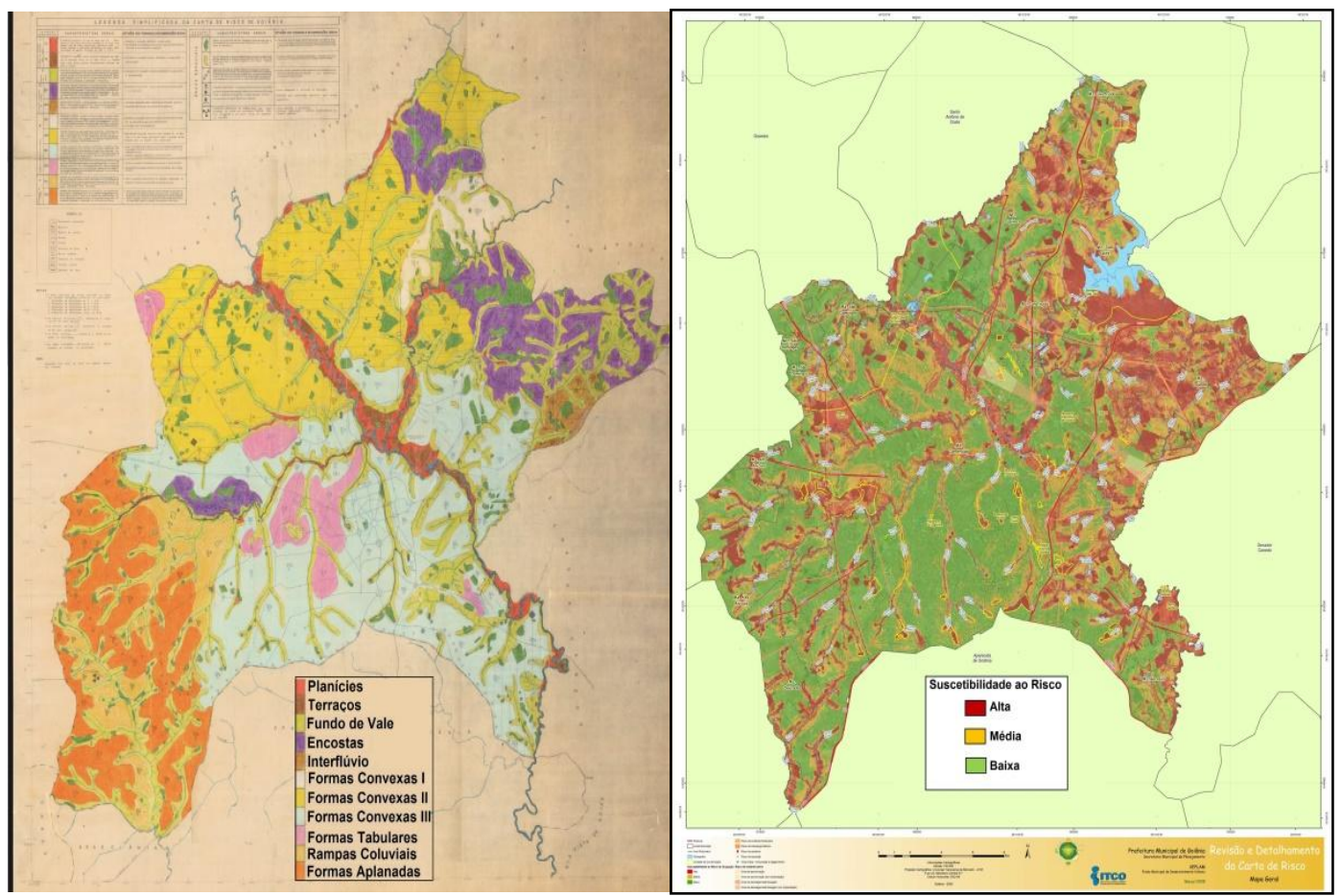

Figuras 9: As Cartas de Risco de Goiânia elaborada em 1993 (A) e atualizada em 2008 (B). Adaptado de: Prefeitura de Goiânia.

Após quinze anos da elaboração da Carta de Risco, técnicos da Prefeitura de Goiânia chegaram à conclusão da necessidade de revisão e atualização deste documento, sobretudo para fomentar outros dispositivos e instrumentos de planejamento e ordenamento territorial municipal. Sendo assim, em 2008 foi publicada a nova Carta de Risco de Goiânia (conforme mostra a Figura 9-B.), indicando como áreas de alta susceptibilidade ao risco a porção nordeste do município e as áreas de fundo de vale das drenagens (em vermelho); e as áreas de média a baixa susceptibilidade ao risco no restante do município, com a indicação de algumas aptidões e restrições.

Com o objetivo de gerir o desenvolvimento das funções sociais da cidade e da propriedade urbana, em 2007 foi lançado o novo Plano Diretor de Goiânia, ainda em vigência. De acordo com o texto do documento (GOIÂNIA, 2007), o este observou as disposições previstas no Estatuto das Cidades e na Lei Orgânica do Município de Goiânia e foi desenvolvido com o intuito maior de assegurar o 
"direito à cidade sustentável, compatibilizando o crescimento econômico com a proteção ambiental, o respeito à biodiversidade e sociodiversidade" - conforme preconizado pela Agenda 21 .

Com o objetivo maior de disciplinar e ordenar o uso do solo, no Plano Diretor afirma-se que foi estabelecida uma macroestruturação fundamentada nas características físico-ambientais, socioeconômicas e culturais, tomando a rede viária básica como elemento de suporte e os corredores do transporte coletivo como componentes estruturantes do modelo de ocupação urbana. Para tanto, o Plano Diretor de 2007 indicou a necessidade de crescimento da cidade associado à dinâmica de sua ocupação concêntrica, paralelamente à sua indução a sudoeste, e definiu critérios e exigências aos novos parcelamentos do solo a serem implantados. Como exemplos, o critério de contiguidade a outro parcelamento já implantado e a obrigação de haver no mínimo $30 \%$ (trinta por cento) de ocupação edificada e ocupada. Essas medidas previam a eliminação dos vazios urbanos identificados no próprio Plano Diretor.

Como controle da "ocupação equilibrada e funcional" e da "densidade populacional" compatíveis com a infraestrutura instalada, a existência de equipamentos urbanos e, considerando as restrições identificadas pela Carta de Risco, o Plano Diretor de Goiânia de 2007 indicou áreas de ocupação diferenciada conforme o grau de consolidação urbana existente, assim: 1) as Áreas de Adensamento em Aceleração, onde seria incentivado o maior adensamento populacional e de atividades econômicas; 2) as Áreas de Adensamento em Desaceleração, para onde seriam dirigidas ações de controle e redução do atual processo de densificação urbana; 3) as Áreas de Adensamento Básico, que apresentavam baixa densidade e onde seriam admitidas a duplicação dos atuais graus de densidade; e 4) as Áreas de Restrição à Ocupação - definidas pela Carta de Risco ou pela existência de equipamentos especiais (no mapa é representado apenas este tipo especial de restrição à ocupação urbana).

\section{As fases de crescimento urbano de Goiânia - GO}

Ao mapear o crescimento urbano de Goiânia e dos núcleos urbanos vizinhos, desde a fundação da capital até o ano de 1980, Corrêa (1981) descreve esse processo em cinco momentos: 1) de 1933 a 1935, com a implantação do Plano Diretor; 2) em 1938, crescimento da malha urbana em sentido sul (ampliação do Setor Sul); 3) de 1940 a 1950, crescimento da cidade no sentido leste-oeste em direção ao núcleo urbano existente antes de 1935 - Campinas (origem dos setores Oeste, Aeroporto, Funcionários etc.); 4) de 1950 a 1960, expansão rumo a oeste e 
estendendo-se para o sul; e 5) após 1960, uma expansão mais desordenada, com formação de vários núcleos habitacionais separados por enormes vazios demográficos. Essa periodização é bem delineada pelo mapeamento feito por Oliveira (2005), representado pela Figura 10, a seguir.

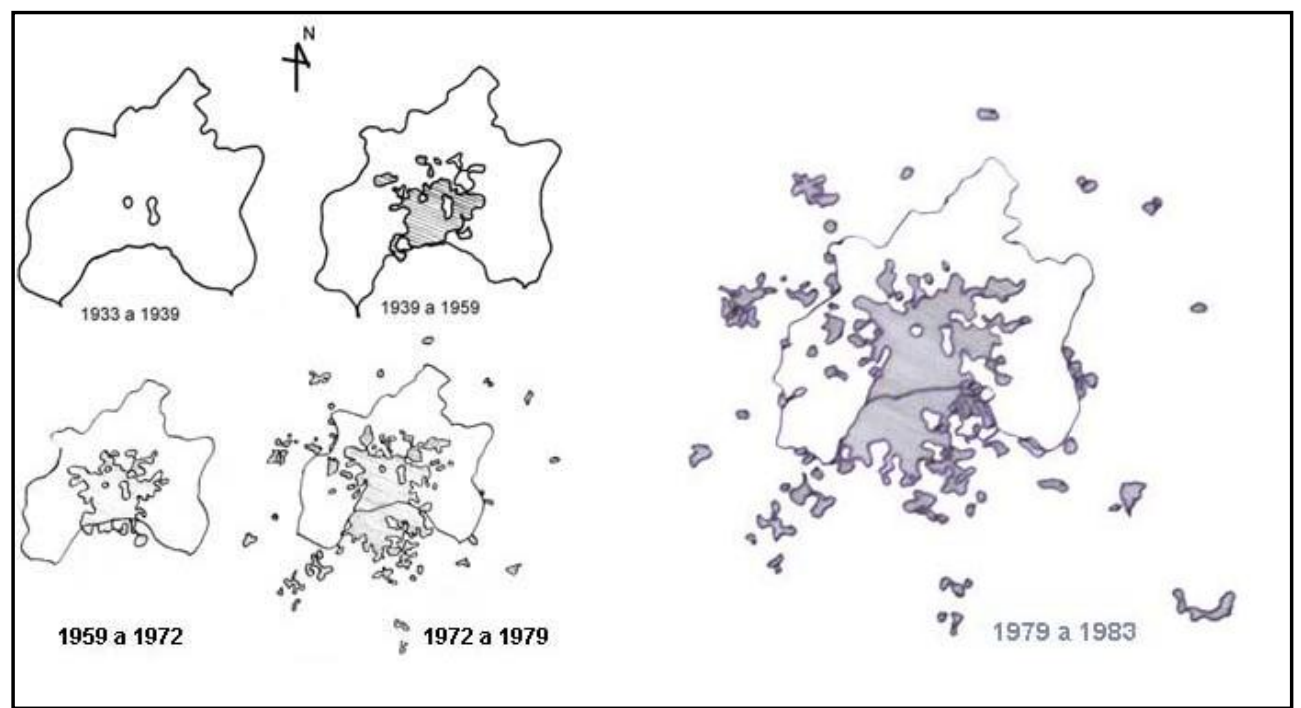

Figura 10: Fases da expansão urbana do Aglomerado Urbano de Goiânia.

Fonte: Vaz (2002 apud OLIVEIRA, 2005).

Ao analisar o padrão territorial de Goiânia, tendo por base as leitura dos Planos Diretores de Goiânia e do Plano de Desenvolvimento Integrado de Goiânia (PDIG, 1992), a arquiteta e urbanista Oliveira (2005) também destaca cinco fases de desenvolvimento em Goiânia: a) 1933 a 1950, a criação do lugar; b) 1950 a 1964, a ampliação do espaço pelo avanço acelerado no número de loteamentos implantados pela iniciativa privada; c) 1964 a 1975, a concentração de lugares no espaço devido a um acelerado crescimento populacional e a multiplicação de loteamentos irregulares; d) 1975 a 1992, a expansão urbana com a implantação de conjuntos habitacionais e; e) 1992 aos dias atuais, os espaços urbanos segregados com a proliferação de condomínios fechados.

Por sua vez, examinando a dinâmica populacional de Goiânia, Rodrigues (2005, p.1) afirma que "nas últimas décadas, com o processo de metropolização, Goiânia, como núcleo da metrópole, vê cair o volume e o ritmo de crescimento populacional 
em favor do crescimento dos municípios do seu entorno imediato" ${ }^{3}$. O que é complementando por Oliveira (2005), que destaca a existência de um notório "processo de ocupação residencial das áreas periféricas em detrimento das regiões mais centrais" - correspondendo aos condomínios fechados.

\section{Mapeamento do crescimento urbano de Goiânia-GO entre 1986 e 2010}

Os produtos cartográficos obtidos por meio da classificação das imagens de satélite ilustram o processo de crescimento da área urbana de Goiânia - GO nos anos de 1986, 1991, 1996, 2000, 2006 e 2010 - como se vê na Figura 11, representada pelos mapas a seguir:
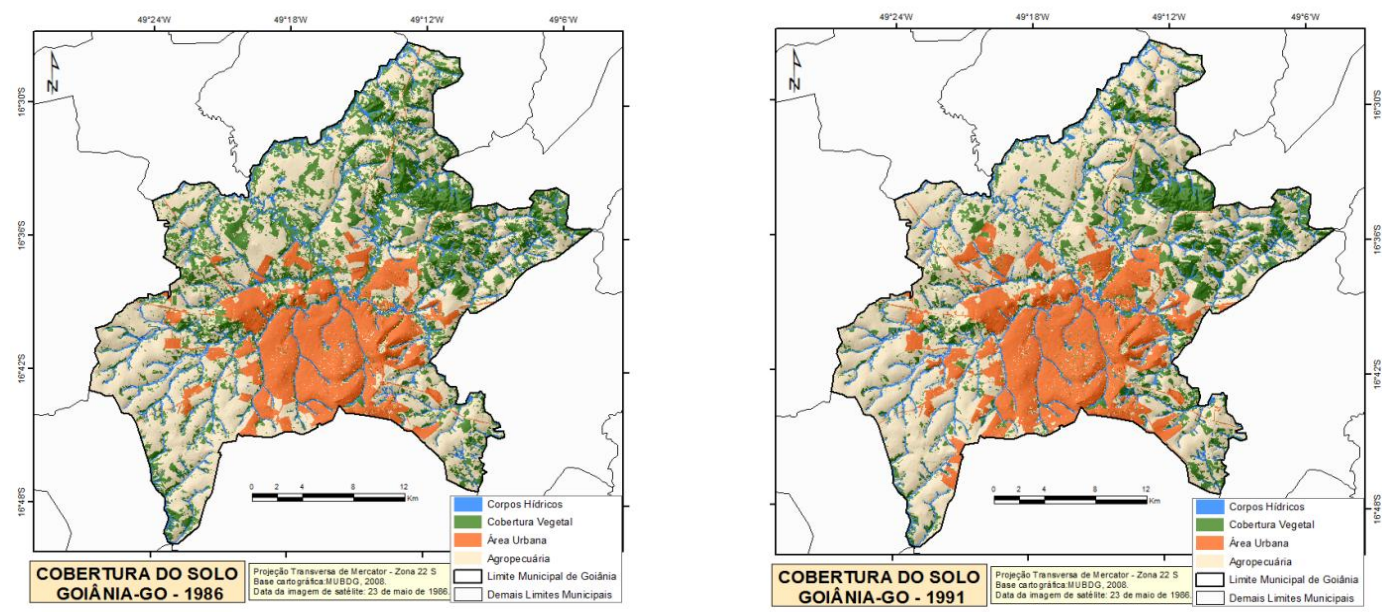

${ }^{3}$ Tal assertiva corrobora ao processo de conurbação com Aparecida de Goiânia (já consolidado), Senador Canedo, Trindade (mais recentemente) e Goianira (em processo). 

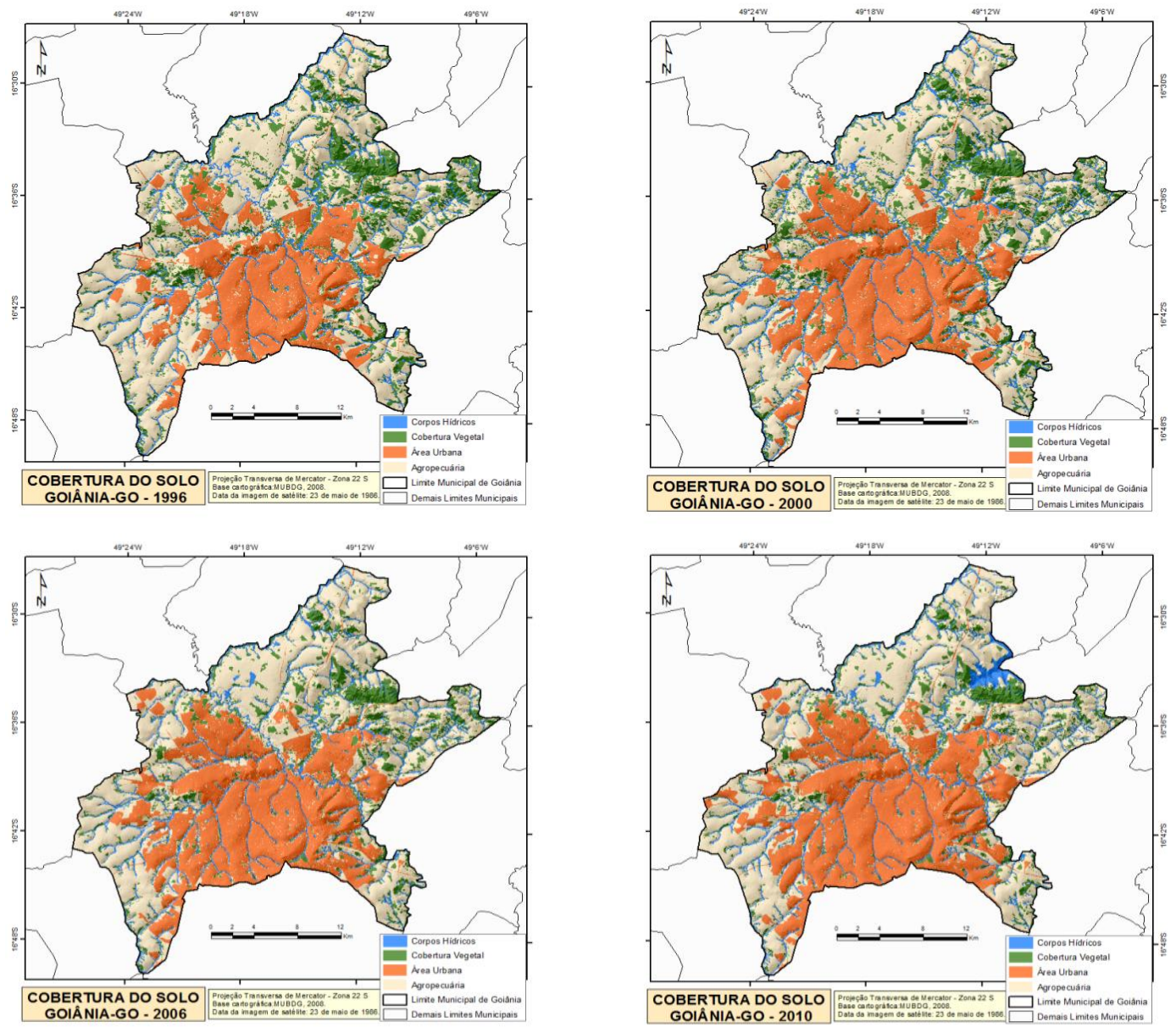

Figura 11: Mapas de Cobertura do Solo de Goiânia de 1986, 1991, 1996, 2000, 2006 e 2010.

As grandes mudanças ocorridas entre 1986 e 1991 foram a intensa supressão da cobertura vegetal para implantação de atividades agropecuárias - facilmente perceptível na porção noroeste do município - e o processo contínuo de crescimento da área urbana, especialmente nas porções sudoeste, constituindo área de reserva de terra urbana para a implantação de empreendimentos habitacionais, e noroeste, caracterizada por loteamentos irregulares - conforme salientado por Rodrigues (2005).

Nas décadas de 1980 e 1990 o crescimento do tecido urbano ocorreu de forma irregular e acelerada, resultando em uma malha urbana descontínua, sendo que a 
periferia cresce mais que o núcleo urbano central, que já se encontra consolidado, sobretudo pelo uso comercial. Além da região central do município, a porção sul também já se encontrava consolidada neste período, inclusive com forte processo de verticalização.

De certa forma, isso respondia aos ditames dos planos diretores de Goiânia à época, que direcionam o crescimento para as partes sul e sudoeste do município, muito embora a implantação dos conjuntos habitacionais em locais afastados e desconectados da malha urbana consolidada tenha gerado custos adicionais ao poder público (além de demora no atendimento) quanto à oferta de serviços de transporte, água, energia, pavimentação etc. Ao mesmo tempo, isso condicionou lucros especulativos aos proprietários das glebas urbanas localizadas entre o núcleo urbano e estes novos espaços urbanizados.

Ainda na década de 1990, conforme representado pelo mapa de Cobertura do Solo de 1996, vê-se o crescimento de setores habitacionais nas regiões periféricas do município separados por vazios demográficos, os quais são ocupados nos anos seguintes (conforme representado pelos mapas de Cobertura do Solo de 2000, 2006 e 2010). Novamente, convém ressaltar o papel do PDIG de 1992, que induzia à ocupação prioritária dos vazios urbanos, além da Carta de Risco, que indicava como áreas aptas à ocupação urbana as porções centro-sul e sudoeste.

Ressalta-se a aparição no mapa de Cobertura do Solo de 2010 de um corpo hídrico de extensão considerável na porção nordeste do município de Goiânia. Trata-se do reservatório da Barragem do Ribeirão João Leite, construído com vistas a assegurar o abastecimento de água tratada para Goiânia e seu entorno até o ano de 2040, e que teve seu enchimento iniciado no final do ano de 2009. A existência do lago reflete, também, a ineficácia da política de controle do município sobre a ocupação da região noroeste de Goiânia, onde está o ponto de captação de água no rio Meia Ponte. Neste caso, o Governo Estadual foi o principal agente responsável, ao instalar conjuntos habitacionais e loteamentos na região, ainda que considerados irregulares pela Prefeitura.

A quantificação das classes de cobertura do solo de cada recorte temporal foi mensurada em ambiente SIG e é apresentada na Tabela 1, abaixo. Chama atenção o fato de que a cobertura vegetal do município de Goiânia sofreu redução de 52,7\% apenas no decorrer dos anos analisados. De uma área de $220,1 \mathrm{~km}^{2} \mathrm{em} \mathrm{1986,}$ passou a $104,1 \mathrm{~km}^{2}$ no ano de 2010. Não obstante, a área urbana, que era de 144,5 $\mathrm{km}^{2}$ em 1986, alcançou uma área de $278,6 \mathrm{~km}^{2}$, no ano de 2010 - um crescimento de $92,8 \%$. 


\begin{tabular}{|c|c|c|c|c|c|c|c|c|}
\hline \multirow{3}{*}{ ANO } & \multirow{2}{*}{\multicolumn{2}{|c|}{ Corpos Hídricos }} & \multirow{2}{*}{\multicolumn{2}{|c|}{$\frac{\text { Vegetação }}{\text { Área }}$}} & \multicolumn{2}{|c|}{ Área Urbana } & \multicolumn{2}{|c|}{ Agropecuária } \\
\hline & & & & & & & & \\
\hline & $\mathrm{km}^{2}$ & $\%$ & $\mathrm{~km}^{2}$ & $\%$ & $\mathrm{~km}^{2}$ & $\%$ & $\mathrm{~km}^{2}$ & $\%$ \\
\hline 1986 & 7,3 & 1,0 & 220,1 & 29,8 & 144,5 & 19,5 & 367,7 & 49,7 \\
\hline 1991 & 7,3 & 1,0 & 163,2 & 22,1 & 173,7 & 23,5 & 395,3 & 53,5 \\
\hline 1996 & 7,5 & 1,0 & 153,0 & 20,7 & 192,9 & 26,1 & 386,1 & 52,2 \\
\hline 2000 & 7,5 & 1,0 & 146,8 & 19,9 & 237,7 & 32,1 & 347,4 & 47,0 \\
\hline 2006 & 7,5 & 1,0 & 109,8 & 14,8 & 261,1 & 35,3 & 361,1 & 48,8 \\
\hline 2010 & 15,3 & 2,1 & 104,1 & 14,1 & 278,6 & 37,7 & 341,5 & 46,2 \\
\hline
\end{tabular}

Tabela 1: Quantificação das classes de cobertura do solo de Goiânia - GO - 1986/2010.

Fonte: Quantificado em SIG e elaborado pelos autores.

Obs.: Área total do município de Goiânia $=739,52 \mathrm{~km}^{2}$.

Conforme destacado anteriormente, a construção da barragem do João Leite, em 2010, propiciou a duplicação da área revestida por corpos hídricos em relação aos anos anteriores. Já as áreas cobertas por atividades agropecuárias tiveram a maior elevação entre os anos de 1986 e 1991 (crescimento de 27,6 km²), apresentando pouco crescimento e até pequenos recuos nos anos seguintes, certamente por terem sido convertidas em ocupações urbanas.

Para melhor compreensão do processo de crescimento urbano de Goiânia, a Figura 12 apresenta os limites das áreas urbanizadas mapeadas em cada período (1986, 1996, 1996, 2006 e 2010). Estando as regiões central e sul já consolidadas, são perceptíveis os vetores de expansão urbana entre 1986 e 1996, principalmente para as regiões noroeste e sudoeste, mas também para as regiões nordeste e leste. 


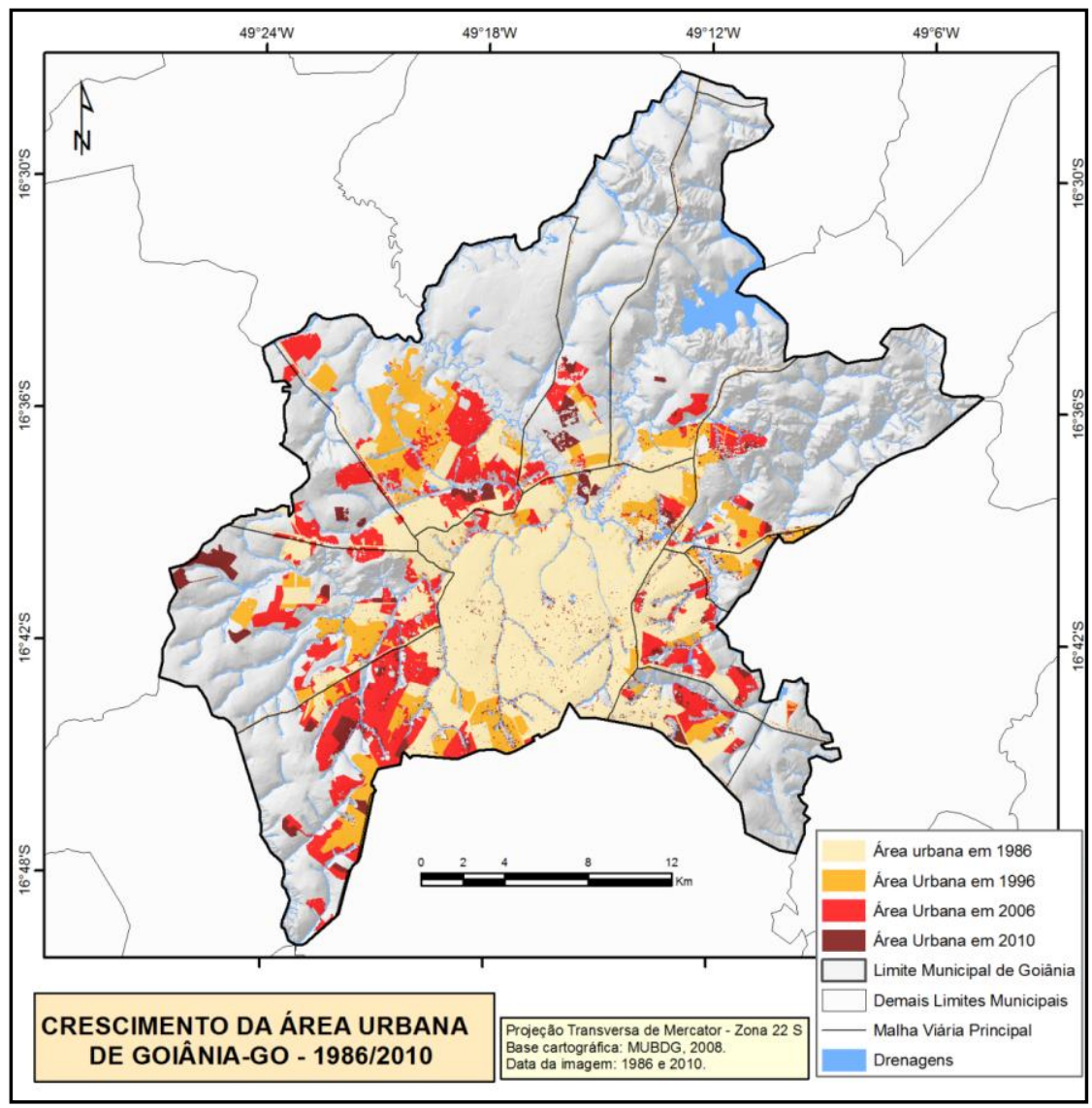

Figura 12:

Crescimento da Área Urbana do município de Goiânia GO entre 1986 e 2010.

Fonte:

Elaborado pelos autores.

De 1996 a 2006 é verificado o vetor de expansão urbana no sentido da região sudoeste, assim como nas direções noroeste e sudeste (esta última em menor intensidade). No referido período, percebe-se um forte processo de preenchimento dos vazios intraurbanos, sobretudo nas regiões sudoeste e noroeste, mas também nas norte e leste. Este "preenchimento" foi fruto, em grande parte, dos ditames legais - como a Lei Orgânica do Município (1990) - que ampliaram as pressões sobre o uso especulativo das terras urbanas, propiciando a venda de muitas glebas até então deixadas como reservas de valor.

Por sua vez, no último período analisado, de 2006 a 2010, percebe-se a consolidação do processo de preenchimento dos vazios intraurbanos ainda existentes, tanto na porção central quanto nas regiões periféricas de Goiânia. Neste período é perceptível também um pequeno vetor de expansão em sentido sudoeste 
e oeste, justamente em algumas localidades definidas pelo Plano Diretor de 2007 como Áreas de Adensamento Básico, que se baseavam em áreas de baixa densidade - indicadas a serem ocupadas. O mapa da Figura 13 mostra a sobreposição do crescimento de Goiânia, desenhado para as três décadas, com as áreas de consolidação urbana definidas pelo Plano Diretor de 2007. Nele é possível identificar a existência de áreas definidas como de "Adensamento Básico" no norte, oeste e sudoeste do município que ainda não tinham sido ocupadas até o ano de 2010, indicando possíveis futuros vetores de crescimento.

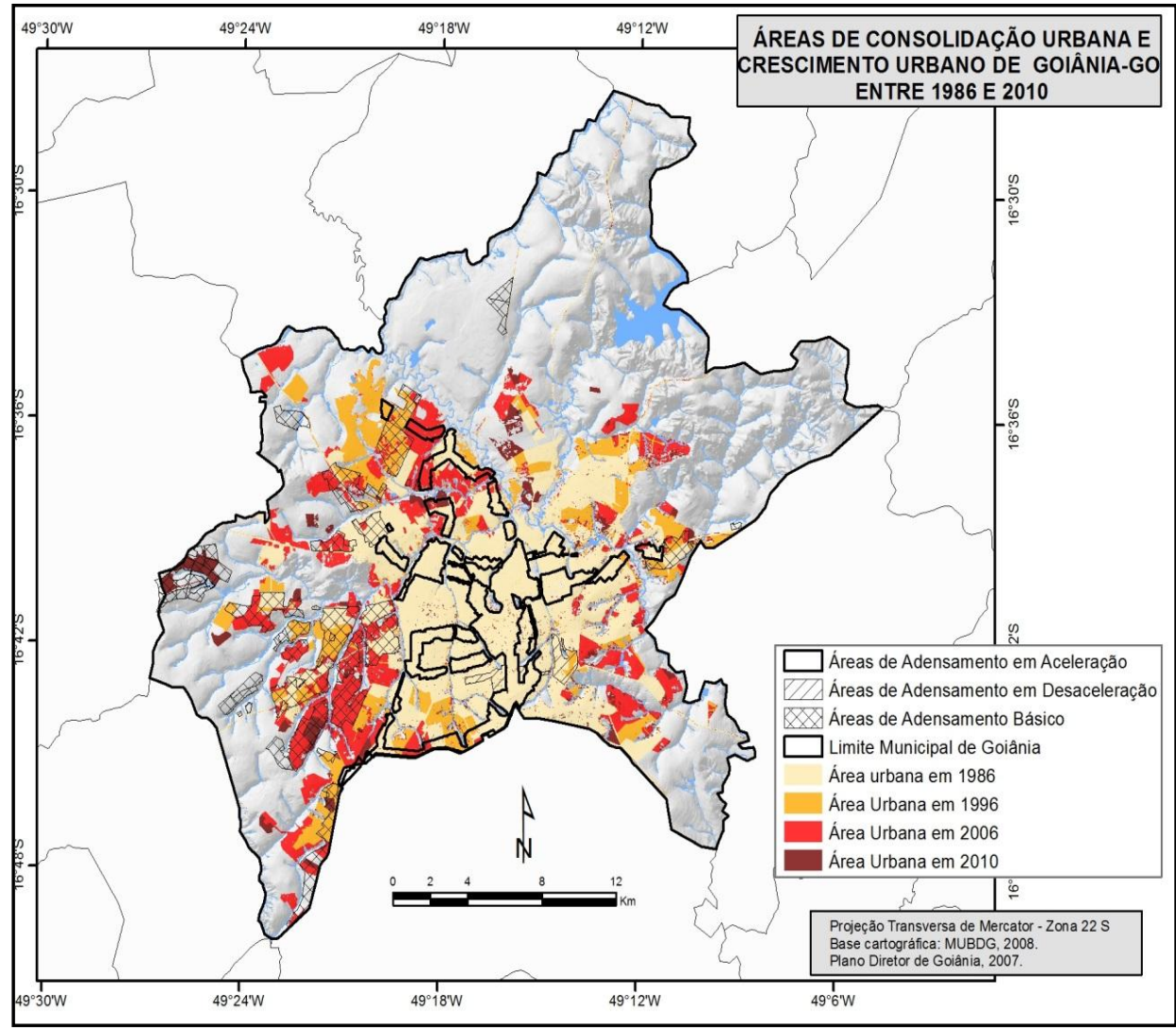

Figura 13: Sobreposição do crescimento urbano de Goiânia (1986/2010) com as áreas de consolidação urbana definidas pelo Plano Diretor de 2007.

Fonte: Elaborado pelos autores.

Convém ressaltar, novamente, as restrições à expansão urbana impostas pela presença da ferrovia, da malha viária, do relevo acentuado e dos mananciais 
utilizados para captação de água para abastecimento público. Por isso mesmo, tanto a região norte quanto a nordeste ainda se encontravam bastante preservadas até o final da década de 1990.

Não obstante, a expansão da mancha urbana que parece estabilizar no limite meridional do município, na verdade ultrapassou essa barreira e se estendeu pelo território do município de Aparecida de Goiânia. Neste sentido, não houve, de fato, uma verdadeira conurbação da mancha urbana das duas cidades e sim um extravasamento do limite sul do crescimento urbano de Goiânia sobre a parte norte do município vizinho. Esse fato é ainda hoje corroborado pelos imensos vazios urbanos que existem em Aparecida de Goiânia, entre seu núcleo urbano original (a região central da cidade) e seus bairros da porção norte, conectados à Goiânia.

\section{Considerações Finais}

O crescimento urbano do município de Goiânia demonstra, claramente, não só as influências do sítio (o meio fisiográfico), que define tanto barreiras geográficas como áreas preferenciais para a expansão urbana (como os terrenos planos), mas também o papel das políticas públicas e a ação da iniciativa privada, que atuam no sentido de direcionar o processo de ocupação, muitas vezes contrariando a própria lógica estabelecida pelo sítio e pela legislação que deveria regular o crescimento urbano.

A revisão bibliográfica e o mapeamento por imagens de satélite permitiram revelar a geografia do processo de crescimento de Goiânia, assim como os vetores preferenciais de expansão da área urbana. Mas isso, por si só, não explica o processo, uma vez que loteamentos surgem desmembrados na mancha urbana consolidada, bairros são instalados em áreas de risco, há ocupações irregulares em áreas de preservação, dentre outras situações.

Embora se possa inferir que a maior parte dos parcelamentos urbanos se insira em uma lógica de mercado, com peso significativo da ação dos agentes imobiliários, compreendê-los exige uma verticalização dos estudos, para buscar sua historicidade e suas funções na demanda social pela moradia - algo premente em um mundo a cada dia mais urbano. 


\section{Bibliografia}

BOGGIONE, G. de A.; et. al. (2009) Definição da escala em imagens de sensoriamento remoto: uma abordagem alternativa. In: SIMPÓSIO BRASILEIRO DE SENSORIAMENTO REMOTO, 14. Anais do XIV SBSR. Natal. pp. 17391746.

CARTA de Risco do Município de Goiânia. (1991) Goiânia: IPLAN et al. 1 mapa, color., $107 \mathrm{~cm} \mathrm{x} 140 \mathrm{~cm}$. Escala 1: 40.000.

CHAUL, N. N. F. (1999) A construção de Goiânia e a transferência da capital. 2. ed. Goiânia: Ed. da UFG.

CORRÊA, E. M. S. (1981) A expansão de Goiânia: uma abordagem cartográfica 1933-1980. Dissertação (Mestrado em Geografia) - Universidade Estadual Paulista, Campus de Rio Claro.

GOIÂNIA, (Município). (1969) Plano de Desenvolvimento Integrado de Goiânia. São Paulo: SERETE Eng. S/A.

GOIÂNIA (Município). (2007) Lei Complementar $n^{o}$. 171, de 29 de maio de 2007. Dispõe sobre o Plano Diretor e o processo de planejamento urbano do Município de Goiânia e dá outras providências. Lex: Legislação Municipal, Goiânia.

INSTITUTO DE DESENVOLVIMENTO TECNOLÓGICO DO CENTROOESTE (ITCO). (2008) Revisão e detalhamento da carta de risco e planejamento do meio físico do município de Goiânia. Goiânia: Prefeitura Municipal de Goiânia. INSTITUTO BRASILEIRO DE GEOGRAFIA E ESTATÍSTICA (IBGE). (2008) Regiões de influência das cidades 2007. Disponível em: <http://www.ibge.gov.br/home/geociencias/geografia/regic.shtm>. Acesso em: 10 out. 2014.

INSTITUTO DE PLANEJAMENTO MUNICIPAL DE GOIÂNIA. (1992) Plano de Desenvolvimento Integrado de Goiânia. Goiânia: IPLAN.

IPEA/IBGE/NESUR-IE-UNICAMP. (1999) Caracterização e Tendências da Rede Urbana do Brasil. Campinas: IE-Unicamp (2 vol.).

LOPES, L. M.; ROMÃO, P. de A. (2006) Geomorfologia urbana da região metropolitana de Goiânia. Guia de Excursões Centro - Oeste, Simpósio Nacional de Geomorfologia. Goiânia.

LUIZ, G. C. (2012) Influência da Relação Solo-Atmosfera no Comportamento Hidromecânico de Solos Tropicais Não Saturados: Estudo de Caso Município de Goiânia. 246f. Tese (Doutorado em Engenharia) - Departamento de Engenharia Civil e Ambiental, Universidade de Brasília, Brasília.

MORAES, S. (1991) O empreendedor imobiliário e o Estado: o processo de expansão de Goiânia em direção sul (1975-1985). Dissertação (Mestrado em Arquitetura e Urbanismo) - Universidade de Brasília. 
NASCIMENTO, M. A. L. S. (1994) Erosões Urbanas em Goiânia. Boletim Goiano de Geografia, n. 14. pp. 77-101.

; PODESTÁ FILHO, A. de. (1993) Carta de Risco de Goiânia. Boletim Goiano de Geografia, n. 1, v. 13. pp. 95-107.

NASCIMENTO, D. T. F.; OLIVEIRA, I. J. de. (2011) Análise da evolução do fenômeno de ilhas de calor no município de Goiânia-GO (1986-2010). Boletim Goiano de Geografia (Impresso), v. 31. pp. 113-127.

NUNES, E. D.; ROMÃO, P. A. (2010) Processos Erosivos Lineares em Goiânia: Uma Avaliação no Período de 1992 A 2007 com Base na Compartimentação em Bacias Hidrográficas. In: ENCONTRO NACIONAL DE GEÓGRAFOS, 2010. Anais do XVI Encontro de Geógrafos Brasileiros. Porto Alegre.

OLIVEIRA, M. das M. B. de. (2005). O padrão territorial de Goiânia: um olhar sobre o processo de formação de sua estrutura urbana. Arquitextos, 065.07, ano 6, out. em: <http://www. vitruvius.com.br/revistas/read/arquitextos/06.065/419>. Acessado em: 06 out. 2014.

REGO, T. L. (2010) Alagamentos e inundações em Goiânia: uma análise a partir da imprensa local e dos registros da defesa civil. Monografia (Graduação em Geografia) - Instituto de Estudos Socioambientais, Universidade Federal de Goiás. RIBEIRO, M. E. J. (2004) Goiânia: os planos, a cidade e o sistema de áreas verdes. Goiânia: Editora da UCG.

SANO, E. E.; ROSA, R.; BRITO, J. L.; FERREIRA JUNIOR, L. G.. (2008) Mapeamento semidetalhado do uso da terra do Bioma Cerrado. Pesquisa Agropecuária Brasileira, v. 43. pp. 153-156.

STREGLIO, C. F. da C.; NASCIMENTO, D. T. F.; OLIVEIRA, I. J. de . (2013) O processo de expansão urbana e seus reflexos na redução da cobertura vegetal no município de Goiânia - GO. RA'E GA: o Espaço Geográfico em Análise, v. 28. pp. 181-197. 